\title{
APOFATICKO-KATAFATICKÝ ROZMĚR MYSTIKY V POJETÍ NIKOLAJE LOSSKÉHO ${ }^{1}$
}

K A R E L S L Á D E K

\section{7} ájem o mystiku a mystickou zkušenost neutuchl ani v současné společnosti. Jedním z významných křestanských myslitelů, kteří se mystikou seriózně zabývali, byl Nikolaj Losskij, jenž žil jako ruský emigrant v prvorepublikovém Československu. Knihy Nikolaje Losského mohou být i v současnosti inspirativní v mnoha ohledech. Jednak se Losskij snažil jasně vymezit pojetí mystiky, respektive obhájit autenticitu mystické intuice, a jednak předkládal rozlišující kritéria a poukazoval na scestná nebezpečí při mystické zkušenosti. Losskij vycházel především z křestanské patristické tradice, dále z mystické teologie východní i západní křestanské tradice, kterou interpretoval skrze svůj originální gnozeologický přístup.

Losskij ve své analýze lidského poznání rozeznával trojí intuici, ve které je zřejmý jeho záměr propojit vnímání světa u empirika, metafyzika a mystika. Kromě statistické analýzy empirických dat využívá taktéž deduktivní filosofickou metodu a mystický vhled do podstaty věcí. Losského tři intuice můžeme shrnout následovně:

(1) smyslová intuice o reálném bytí, tedy vše s časoprostorovou formou, která má transsubjektivní charakter vztahující se k vnější skutečnosti;

(2) intelektuálni intuice o mimoprostorovém a mimočasovém ideálním bytí, které se realizuje v konkrétní skutečnosti a které člověk kontempluje $\mathrm{v}$ jeho přirozené realitě;

(3) mystická intuice, tedy mystická zkušenost nahlížející všejednotící metalogické bytí, které dává smysl veškerému dění. ${ }^{2}$

1 Článek je výstupem z grantu GAAV IAA908280902 s názvem „Život a vliv Nikolaje Losského v akademickém světě prvorepublikového Československa“.

2 Srov. LOSSKIJ, Nikolaj. Filosofia intuitivizmu. Poprad: Christiania, s. 31-69. 
Třetí typ intuice - mystická intuice - bude předmětem tohoto článku. V následujících řádcích bude analyzována první část Losského díla Mystická intuice v kontextu současného bádání spirituální teologie. Spirituální teologie se jako vědecká disciplína zabývá duchovním rozvojem osobnosti člověka: od jeho počátku (obrácení) přes vnitřní proměnu (očištění) Duchem svatým a postupné vrůstání do podobenství boholidské podstaty Krista (osvícení) až po dosažení svatosti (dokonalé zbožšténi ve sjednocení), čímž člověk svátostným životem církve intimně vrůstá do života Osob Boží Trojice. ${ }^{3}$ Mystika je potom onen nepopsatelný okamžik sjednocení, během kterého dojde k láskyplnému vlitému zakoušení Boha za předpokladu vnitřní očisty. Mystický dotek přetváří a utváří život proměňujícího se člověka. Jde o zvláštní náboženský prožitek, při němž je duchovní zkušenost prožívána jako niterná a bezprostřední. ${ }^{4}$ Spirituální teologie ve vztahu k mystice zaujímá postoj služby ve smyslu rozlišení a garance autenticity, zároveň naslouchá, zhodnocuje a asimiluje autentickou mystickou zkušenost v teologických disciplínách.

Nikolaj Losskij napsal svou studii Mystická intuice původně v ruském jazyce $\mathrm{v}$ roce 1938, avšak v tomto originále nebyl text nikdy publikován. Následně tvořil integrální součást Losského díla Smyslová, intelektuální a mystická intuice. Původní text byl však v anglickém překladu pořízeném samotným Losským vytištěn v Praze s názvem $M y s$ tical Intuition. V této kapitole budu vycházet z obou textů. Obsahově se zaměřím na Losského pojetí apofatického a katafatického rozměru křestanské mystiky.

Úvodní studii pojednání o mystické intuici, která je v ruské verzi nazvána jako Božské nic a v anglické jako Kognitivní hodnota mystické zkušenosti, věnoval Losskij velmi stručnému shrnutí svého intuitivismu, snažil se obhájit autenticitu a objektivitu mystické zkušenosti, varoval před upadnutím do panteismu a neosobní spirituality, aby v závěru popsal stupně mystické zkušenosti u křestanských mystiků.

První řádky Losskij věnuje především otázce poznání Absolutna a jeho vztahu ke světu. Citoval ruského emigranta Simona Franka, pro kterého jisté „A“ může existovat jen díky vztahu k „non-A“, ale v Losského interpretaci Frank „téměř ztotožnil Absolutno, tedy Boha,

3 Další možné definice spirituální teologie - srov. KOHUT, Pavel Vojtěch. Co je spirituálni teologie? Kostelní Vydří: Karmelitánské nakladatelství, s. 37.

4 Srov. MOIOLI, Giovanni. Mystika křestanská. In FIORES, De Stefano - GOFFI, Tullo (ed.). Slovnik spirituality. Kostelní Vydří: Karmelitánské nakladatelství, 1999, s. 543. 
se světem, čímž se velmi přiblížil k panteismu, s čímž nelze souhlasit“.5 Také Frank se k některým Losského pozicím vyjádřil kriticky, když napsal:

Teorie Losského obsahuje přesto podstatnou mezeru. Její pomocí se sice zaručuje ideální uchopení předmětu poznávajícím vědomím, avšak vlastně jen pro okamžik uchopení sebe sama! Pojem jsoucna sám, v celé jeho transcendenci, tj. jeho nezávislosti od každého poznání, se tím dostatečně nevysvětluje,

míní Frank a dodává:

Na otázku kritické filosofie: jest jsoucno vně nás nebo uvnitř nás? Musí být odpověděno, že oboje je zároveň tím zaručeno, že my jsme uvnitř jsoucna. ${ }^{6}$

Bůh je ve Frankově vizi vnímán jako jsoucno, které je člověkem vnitřně osvojováno. Losskij v jeho vizi absolutní Všejednoty, jež zahrnuje jednotu i rozmanitost, shledal umenšení transcendentní kvality Boha, který jakožto nejvyšší Bytí přesahuje světový systém. Frankova teorie Boha jakožto původní prajednoty je podle Losského v rozporu s tvrzením, že svět byl stvořen z ničeho, bez původní prajednoty. Stvoření vnímal Losskij v souznění s aristotelsko-tomistickou tradicí jakožto akt Prvotní příčiny.

Vždyt' jako jeho příčina je s ním [se světem] neměřitelný a jako Bytí samo v sobě nemá žádné př́činy. Tvrzení, že svět je založen na takovém principu, nutně vede $\mathrm{k}$ myšlence $\mathrm{o}$ absolutním stvoření světa $\mathrm{z}$ ničeho $\mathrm{v}$ tom smyslu, že Stvořitel nepoužívá žádnou materii odněkud mimo sebe nebo ze sebe, ale tvoří svět co do formy a obsahu jako něco nového, jako něco úplně jiné. ${ }^{7}$

Poznání totální jinakosti Boha od stvořeného světa, jeho nevyjádřitelnost a nedefinovatelnost jakýmikoliv termíny stvořeného bytí, což vyjadřuje Losskij jako Božské „Nic“, je základem apofatické teologie, ve které lze metodou negace s jistotou pouze definovat, kým Bůh

5 LOSSKIJ, Nikolaj. Чувственная, интеллектуальная и мистическая интуциия. Moskva: TERRA-Knižnyj klub, 1999, s. 259.

6 FRANK, Simon. Ruský světový názor. In PELIKÁN, Ferdinand (ed). Současná ruská filosofie. Sbornik statí. Praha: Nákladem České grafické unie, 1929, s. 51.

7 LOSSKIJ, Nikolaj. Чувственная, s. 260. 
není. Losskij již toto mystické poznání přijímá jako autentické, avšak varuje před scestím. Pokud totiž člověk ustrne pouze u negace, může se stát, že v rámci tohoto částečného poznání identifikuje Absolutno neosobně jako „propast nirvány“. 8 Losskij argumentoval, že lidé obdaření Duchem svatým se mohou povznést k nadkosmickým výšinám a v negaci všech nedostačujících či falešných označení Absolutna se setkají s osobním Bohem v pozitivním aspektu, při navázání vlitého láskyplného vztahu.

Tak tomu bylo u největšího starověkého filosofa Plotina a také u jednoho z velikých církevních otců, kterého díla jsou připsána Dionýsiu Areopagitovi, ale jeho skutečné jméno neznáme. Areopagita se nebojí negací; každá negace se pro něho stává největším potvrzením. Nic pro něho znamená vše, co je nad myšlením [pozn. v ruštině: co je Nad], ne-dobro znamená svrchované Dobro [pozn. v ruštině: Naddobro]. Bůh je pro něho bytí a jednotu přesahující počátek. ${ }^{9}$

Syřan píšící pod pseudonymem Dionýsios Areopagita se stal pro Losského autorem velmi inspirativním. Postavil svou vizi na novoplatonické myšlence sestupného vyplynutí všeho z jednoho Počátku a vzestupného návratu. ${ }^{10}$ Počátkem a cílem však není Jedno, ale křestanský osobní Bůh. ${ }^{11}$ Pro Losského proto byla nepřijatelná příliš platonicky orientovaná Frankova vize o původní Prajednotě, proti čemuž hájil stvoření světa z ničeho. Drží se striktně filosofické interpretace křestanského popisu stvoření světa z prvních kapitol starozákonní knihy Genesis.

Negace je tedy přirozeným prvním krokem pro pochopení a uznání reality Absolutna, které přesahuje příliš lidské myšlení o Něm. První mystickou zkušeností člověk uznává nepoznatelnost a pojmovou neuchopitelnost Boha, ovšem v afektivní mystické zkušenosti zakouší

8 LOSSKIJ, Nikolaj. Чувственная, s. 261.

9 Tamtéž.

10 Srov. Hier. Coel. 1,2/Corp. Dion. II, 7,4-8, cit. in KARFÍKOVÁ, Lenka. Studie z patristiky a scholastiky. Praha: OIKOYMENH, 1997, s. 114.

11 Bůh jako Počátek všeho není ve vztahu k veškerenstvu neutrální, naopak k němu má intenzivní a láskyplný vztah, jak píše Dionýsios v díle $O$ božských jménech: „Od Ní získávají život všichni živočichové a rostliny a Ona o ně pečuje. A můžeš vyjmenovat jakýkoliv typ života, inteligibilní, rozumový, pocitový, sytící, vegetativní či jakýkoliv jiný, anebo životní princip nebo podstatu, ale stejně vše pochází z Ní, která jakýkoliv život převyšuje, žije jím a oživuje jej, a v Ní jako v příčině vše jednotně praexistuje“ In SV. DIONÝSIOS AREOPAGITA. O mystické teologii. O božských jménech. S komentáři Sv. Maxima Vyznavače. Praha: Dybbuk, 2003, s. 180-181, pozn. velká a malá písmena byla ponechána podle překladu Alana Černohouse. 
jednotu s Ním v lásce. Zjevení osobního Boha formuje pozitivní aspekt obsahu mystického poznání, které následuje po všech negacích, čímž se zabývá katafatická teologie. V rámci poznání biblického zjevení a vlastní kvalifikované zkušenosti se zjevením definuje základní dogmatické pravdy. Losskij obhajuje nutnost katafatické teologie pro stanovení kritérií autenticity mystické intuice.

I při tom nejnepatrnějším přiblížení se $\mathrm{k}$ tomuto nevýslovnému majestátu je duch člověka uchvácený, což svědčí o tom, že již překročil sféru čistě abstraktního logického myšlení. Stal se hoden, i když jen v malé míre, aby vstoupil do konkrétního společenství s nadkosmickým principem nejen rozumem, ale i citem - přesněji vyjádřeno - láskou,“ píše Losskij a dále rozvádí: „Když odpovíme na jeho volání i jen malou láskou, věrně a spolehlivě dokáže, že je s námi, že je v našem vlastním srdci a naše duše bude prozářena ,radostí v Hospodinu“ - pocitem nevýslovného štěstí, a to již z čistého poznání, že existuje tak dokonalé Bytí. ${ }^{12}$

„Radost v Hospodinu“ je podle Losského přítomna u mystiků katolické i pravoslavné tradice, kdy vyjmenovává Bernarda z Clairvaux, Jindřicha Susa, Terezii z Avily, Serafima Sarovského či postavu poutníka z díla Uprímná vyprávéni poutnika svému duchovnímu otci. Losskij se tímto výčtem stává myslitelem vpravdě ekumenickým, jelikož uznává autentickou svatost osobností napříč křestanskými konfesemi. Spojuje mystické cesty, které mnohdy bývají rozdělovány do různých typologií a klasifikací: mystika bytnosti rýnsko-vlámské školy (Jindřich Suso), snubni mystika (Terezie z Avily) ${ }^{13}$ či hesychastická mystika „světla hory Tábor" (Serafim Sárovský). ${ }^{14}$

Objektivitu náboženské zkušenosti Losskij dokumentoval na díle Rudolfa Otto s názvem Posvátno, ve kterém transcendentní Absolutno vzbuzuje fascinaci i bázeň zároveň. Před pozitivistickým subjektivismem a psychologismem Losskij hájil objektivitu afektových stavů v mystické zkušenosti.

Zkušenost, která nás vede do oblasti Posvátna, je společná i v té nejelementárnější formě obrovské většině lidí. Bez ní by nevzniklo žádné náboženství.

12 LOSSKIJ, Nikolaj. Чувственная, s. 261.

13 Srov. MOIOLI, Giovanni. Mystika křestanská, s. 543.

14 Srov. ŠPIDLÍK, Tomáš. La mistica ortodossa. In Aa. Vv. Sentieri illuminati dallo Spirito. Atti del Congresso internationale di mistica Abbazia di Münsterschwarzach. Roma: OCD, 2006, s. 369-384. 
Při pokusu vyjádřit ji ve formě soudu se lehko sklouzne do zkreslování a dezinterpretace. A přece je náboženství v lidském vědomí nezničitelné, naproti tolik nepřátelským silám, které stojí proti němu. Když se říká, že tato zkušenost je čímsi výjimečná, že ji mohou zažít nemnozí, obyčejně se tím myslí její nejvyšší stupně, které se vyskytují u lidí, kteří dosáhli vysoké úrovně mystické intuice. ${ }^{15}$

Losskij si byl vědom, že duchovní život je dynamický a rozvíjející se proces, proto opět předkládal nauku Dionýsia Areopagity se třemi stupni duchovního rozvoje jednotlivce: očištění, osvícení a sjednocení, ve kterých se též zdokonaluje schopnost rozpoznání a rozvinutí mystické intuice. Člověk se v očistné fázi snaží aktivně, asketickými cvičeními, krotit nezřízenou smyslnost a hříšné vášně, osvobozuje se od vnitřního otroctví, osvícenou modlitbou a meditací se koncentruje na Boha, aby završením všech snah byl prožitek mystické jednoty s Bohem. K mystickému vyvrcholení dochází podle Losského ve formě extáze nebo na ještě vyšším stupni snubním sjednocením s Bohem.

Pokročilé stupně mystické jednoty s Bohem bývají doprovázené stavem extáze, ve kterém někdy dochází k úplné ztrátě vědomí a stavu katalepsie (křečovité stahy svalstva, strnulost apod.). Existuje ovšem ještě vyšší stupeň společenství s božským životem - někteří mystici ho nazývají svatbou duše s Bohem - a to tehdy, když je vědomí zachováno a v tělesném životě nedochází k žádným patologickým změnám, přičemž život duše dosahuje neobyčejné intenzity, a to jak uvnitř, tak i ve vnější praktické činnosti. ${ }^{16}$

Losskij se jako pravoslavný autor opíral též o karmelitánskou mystiku Jana od Kříže, podle kterého prvotní soustředění se na představy je pro začátečníky, proto na počátku nepřikládal netělesným extázím př́liš velkou hodnotu, ale až když se duše zřekne všech „módů“ smyslových i duševních, po „noci smyslů“ a „noci ducha“, sjednotí se ve snubním svazku s Bohem. „Mystika noci“ byla Nikolaji Losskému inspirativní v mnoha ohledech. V tom se odlišuje od některých reflexí o mystické teologii svého syna Vladimíra Losského, který křestanskou „mystiku světla“, jak ji rozvinula tradice křestanského východu, kriticky porovnává s tradicí „mystiky noci“ či „mystiky temnoty“ př́tomné v křestanské západní tradici. Vladimír Losskij ve své proslulé knize Studie mystické teologie V'́chodni Církve popisoval tyto dvě cesty jako dva zcela odlišné

15 LOSSKIJ, Nikolaj. Чувственная, s. 263.

16 Tamtéž. 
způsoby, jak dosáhnout svatosti. Stav „mystických noci““ Vladimír Losskij (neštastně) interpretoval jako upadnutí do hř́šné akédie, respektive do stavu duše v totálním smutku, vnitřní nestabilitě, frustraci, depresi a otupělosti. Nicméně alespoň v poznámce pod čarou Vladimír Losskij připouštěl, že není možné aplikovat toto tvrzení pro všechny případy, absolutizovat ho, protože se ve východní i západní křestanské mystické tradici naleznou světci, kteří spíše potvrzují přítomnost obou duchovních fenoménů napříč křestanskými denominacemi. Jako případ „mystické noci“ uvedl příklad Tichona Voroněžského. ${ }^{17}$

Obdobně jako Nikolaj Losskij i Tomáš Špidlík ve svých početných knihách o spiritualitě východního křestanství nejednou poukázal na vzájemnou provázanost západní „dionýsiovské mystiky temnoty“ a východní „evagriánské mystiky světla“, jak byly rozvinuty ve spiritualitě křestanského Východu a Západu. ${ }^{18}$ Budoucnost bádání v mystické teologii je jistě v hledání prvků, které křestanskou mystiku tajemně sjednocují, jak tento ekumenický rozměr křestanské spirituality předkládá též Nikolaj Losskij. Apologetický podtón při porovnávání těchto dvou vzájemně se doplňujících mystických cest by měl pomalu vymizet z teologických reflexí. ${ }^{19}$ „Mystika noci“ detailněji analyzuje fázi „očištění“, kdežto „mystika světla“ centralizuje svoji pozornost na fázi „osvícení“, a obě fáze směřují k mystickému „sjednocení“ s Boží Trojicí.

\section{ABSTRACT \\ KAREL SLÁDEK \\ Apofatic-catafatic dimensions of mystique in the concept of Nicholas Losskij}

The article analyzed the first part of the work of Nicolas Losskij Mystical's intuition in the context of current research in the spiritual theology. Negation is - according to Losskij - the first natural step for understanding and recognition of the reality of Absolute, and followed by recognition of God's love. Apofatic and catafatic theology is in mystical experience complementary.

\section{Key words}

mystique, mystical intuition, Absolute, apofatic theology, catafatic theology

17 Srov. LOSSKIJ, Nikolaj. Очерк мистического богословия Восточной Церкви. Догамтическое богословие. Moskva: SEI, 1991, s. 170.

18 Srov. ŠPIDLÍK, Tomáš. La mistica ortodossa, s. 369-384.

19 Srov. SLÁDEK, Karel. Východiska pro (nejen) křestanskou mystiku. Teologické texty 2008, č. 1, s. 20-22. 